\title{
Prevalence and associated factors of depressive state among pulmonary tuberculosis patients in Manila, the Philippines
}

\author{
S. Masumoto, * T. Yamamoto, * A. Ohkado, ${ }^{\ddagger \neq}$ S. Yoshimatsu, ${ }^{\ddagger \neq}$ A. G. Querri, ${ }^{\ddagger}$ Y. Kamiya* \\ * Graduate School of International Health Development, Nagasaki University, Nagasaki, Japan; ${ }^{\dagger}$ Research Institute of \\ Tuberculosis, Japan Anti-Tuberculosis Association Philippines Inc, Manila, The Philippines; ₹Research Institute of \\ Tuberculosis, Japan Anti-Tuberculosis Association, Kiyose, Japan
}

S U M M ARY

SETTING: Both depression and tuberculosis (TB) are global public health problems that have a substantial impact on human health. However, depressive state among TB patients has not been well investigated in the Philippines.

OB JECTIVE: To assess depressive state among pulmonary tuberculosis (PTB) patients and to identify factors associated with depressive state in Manila, the Philippines. DESIGN: A cross-sectional survey of PTB patients was conducted at 10 public health centres and two nongovernment organisation clinics providing DOTS in District I, Tondo, Manila. Face-to-face interviews with 561 PTB patients using a structured questionnaire were conducted.

RESULTS: Depressive state was observed in $16.8 \%$ of the participants. Logistic regression analysis indicated that body mass index $<18.5 \mathrm{~kg} / \mathrm{m}^{2}$, marital status of cohabitation compared with married, four or more symptoms, four or more adverse drug reactions, grade 3 or higher on the Medical Research Council dyspnoea scale and low perceived confidant social support were significantly associated with depressive state.

CONCLUSION: Depressive state among PTB patients in economically depressed areas is common, and screening for depression in the primary care setting can identify patients who need support and treatment, especially for malnourished patients and those with poor social support.

KEY WORDS: malnutrition; social support; mental health
TUBERCULOSIS (TB) remains a global public health problem, with approximately 8.7 million incident cases and 1.4 million deaths in $2011 .^{1}$ In the Philippines, one of the world's 22 high TB burden countries, TB is a major cause of morbidity and mortality. $^{2}$ Although case detection and treatment success rates have exceeded the global target since 2005, after the implementation of DOTS strategy, ${ }^{3}$ the prevalence and incidence of TB are still high.

Depression is also an important global public health problem, associated with increased functional disability and mortality, and the World Health Organization estimates that more than 350 million people suffer from depression. Depression is a common mental disorder, accounting for $4.4 \%$ of total disability$\rightarrow$ adjusted life years. ${ }^{4}$ However, the majority of those with mental health problems are not diagnosed or are treated ineffectively in low- and middle-income countries. $^{5}$ Moreover, people with mental health conditions such as depression comprise a vulnerable group who need medical and social intervention.

It is well known that there is a high prevalence of depression among people with chronic diseases, ${ }^{4}$ and several studies have reported that psychiatric morbidity is high in TB patients. ${ }^{6-12}$ Depression has been reported to be associated with poor treatment adherence in chronic diseases, ${ }^{13}$ which can lead to more patients defaulting and a lower treatment success rate. An earlier study showed that older age, low financial status and persistent cough were associated with depression in Nigeria. ${ }^{14}$ However, little is known about the prevalence of depression among TB patients, and few studies have investigated factors associated with mental health among TB patients.

The present study aimed to describe the prevalence of depressive state and investigate associated factors among TB patients in an economically depressed area in Manila, the Philippines.

\section{METHODS}

\section{Study design}

This was a cross-sectional survey conducted to describe depressive state, and other social factors among pulmonary tuberculosis (PTB) patients under DOTS.

Correspondence to: Shoichi Masumoto, Graduate School of International Health Development, Nagasaki University, 1-124 Sakamoto, Nagasaki City, Nagasaki 852-8523, Japan. Tel: (+81) 95819 7008. Fax: (+81) 958197230 . e-mail: smash422@hotmail.co.jp

Article submitted 9 May 2013. Final version accepted 6 October 2013. 


\section{Study site}

District I, Tondo, a congested area in Manila where most of the population is socio-economically deprived, is considered representative of the poor, congested urban areas in the Philippines. The population is estimated to be approximately 410000 in an area of $5.64 \mathrm{~km}^{2}$, of whom 195980 (47.8\%) are economically underprivileged. There are 10 public health centres and two clinics run by non-government organisations (NGOs) providing DOTS in this area.

\section{Subjects}

Study participants were recruited from among PTB patients who were newly diagnosed or undergoing retreatment under DOTS between September and November 2012. Patients with drug resistance, extrapulmonary $\mathrm{TB}$, aged $<18$ years, or who were pregnant, critically ill, or had communication problems or severe complications such as cancer, were excluded. All cases of PTB were diagnosed according to the $\mathrm{Na}$ tional Tuberculosis Control Programme (NTP) guideline in the Philippines. ${ }^{15}$

\section{Data collection}

Recruitment was conducted at each health facility using consecutive sampling of PTB patients confirmed by the TB register, except for those who were not eligible. Patient interviews were conducted by three data collectors using a structured questionnaire. The structured questionnaire was designed to assess sociodemographic factors such as working status, marital status, monthly income, education level, alcohol consumption, smoking status, exposure to second-hand smoke, symptoms and adverse drug reactions (ADRs). Three tools were included in the questionnaire to evaluate depressive state, social support and severity of dyspnoea. The questionnaire was translated into Tagalog from the English using the forward-backward translation method. Patient information about treatment was collected from the TB register and the NTP treatment card at the health facilities.

Data collectors were recruited from the local population and given 2 days' training in conducting standardised interviews. A pre-test was conducted at one NGO clinic not located at the study site to confirm the feasibility and validity of the questionnaire before conducting the study.

\section{Tools}

\section{Depression (Patient Health Questionnaire)}

To assess depressive state among PTB patients, a Patient Health Questionnaire (PHQ-9) was used. The PHQ-9 consists of 9 questions that correspond to 9 criteria for unipolar major depression per the Diagnostic and Statistical Manual of Mental Disorders, Fourth Edition, Text Revision (DSM-IV-TR).16 The questionnaire requests respondents to answer how often they have experienced depressive symptoms during the previous 14 days, and each question has a 3-level rating scale: $0=$ not at all, $1=$ several days, $2=$ more than half the days, $3=$ nearly every day. Total scores range from 0 to 27 and indicate the severity of depression. PHQ-9 scores can be dichotomised with a cut-off score of 10 , with high sensitivity and specificity. ${ }^{17,18}$ PHQ-9 was selected for the study as it has been used universally for research in primary care settings, and in TB patients by another study. ${ }^{14}$ In addition, the questionnaire is very short, requiring only a few minutes to complete. In terms of diagnostic performance in patients with comorbidities, it has been reported that the psychometric properties of the questionnaire are similar to other questionnaires such as the Hospital Anxiety and Depression Scale and the Center for Epidemiological Studies (Utah State University, Logan, UT, USA) Depression Scale (CES-D), ${ }^{19,20}$ although no comparative study with other questionnaires has been conducted in TB patients. Cronbach's $\alpha$ of the items of the PHQ- 9 questionnaire used in the present study was 0.757 , showing high internal consistency.

\section{Social support (Duke-UNC Functional Social Support Questionnaire)}

The Duke-UNC Functional Social Support Questionnaire (FSSQ), used to assess social support, has been widely used in two areas: confidant support and affective support. ${ }^{21}$ The questionnaire consists of eight items with a 5-point scale ranging from 1 (much less than I would like) to 5 (as much as I would like). FSSQ scores can range from 1 to 5, and higher scores reflect higher perceived social support. In this study, FSSQ scores and scores of each area were dichotomised into low and high perceived social support group, taking the 15th centile of the score as the cut-off point. Cronbach's $\alpha$ for the FSSQ was 0.803 , showing high internal consistency.

\section{Medical Research Council dyspnoea scale}

The Medical Research Council (MRC) dyspnoea scale, which consists of five degrees of breathlessness, was used to assess the severity of lung disease. ${ }^{22}$

\section{Statistical analysis}

Data were double-entered into a Microsoft Access 2010 database (Microsoft, Redmond, WA, USA) and validated for any discordance. All statistical analyses were conducted using STATA 12.1 (Stata Corp, College Station, TX, USA). A cut-off score of 10 was used for dichotomising PHQ-9 scores into non-depressive state (PHQ-9 $\leqslant 9$ ) and depressive state (PHQ-9 $\geqslant 10$ ) in this study. On univariate analysis, PHQ-9 was analysed using the $\chi^{2}$ test. Independent variables related to dependent variables on univariate analysis $(P<0.20)$ were chosen for analysis in the multivariate models. In a logistic regression model, a backward-forward stepwise selection procedure, with a probability of 0.10 for removal and a probability of 0.05 for entry, was used to identify associated variables. Age, sex 
and treatment phase were also included in multivariate analysis for adjustment. Significance tests were two-sided, with $P<0.05$ considered statistically significant. Results are reported as adjusted odds ratios (aORs) and their 95\% confidence intervals (CIs).

\section{Ethical considerations}

Ethical approval was obtained from the Department of Health Research Ethics Committee in the Philippines and the Institutional Review Board of the Graduate School of International Health Development, Nagasaki University, Nagasaki, Japan. In addition, research permission was obtained from the Manila City Health Department and each health centre, including the two NGO-run clinics. Study participants were informed of the overview and the importance of the study as well as the risks and benefits. Written informed consent was then obtained from each participant.

\section{RESULTS}

\section{General}

In total, 703 patients were identified by the TB register as having PTB treated under DOTS: 44 of these patients were excluded for reasons shown in the Figure. Of the 659 eligible patients, 561 were interviewed, for a respondent rate of $85.1 \%$; 98 patients could not be recruited as they did not visit the health facilities

All TB patients aged $\geq 18$ years on DOTS $(n=703)$

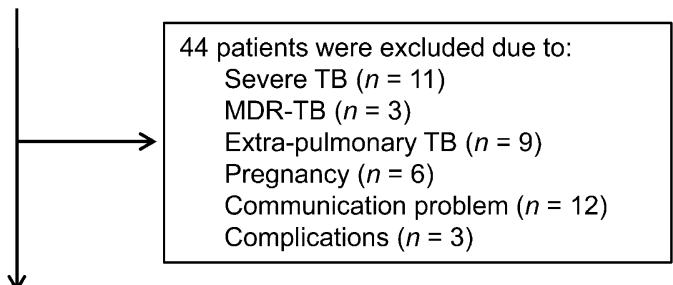

Eligible PTB patients under DOTS $(n=659)$

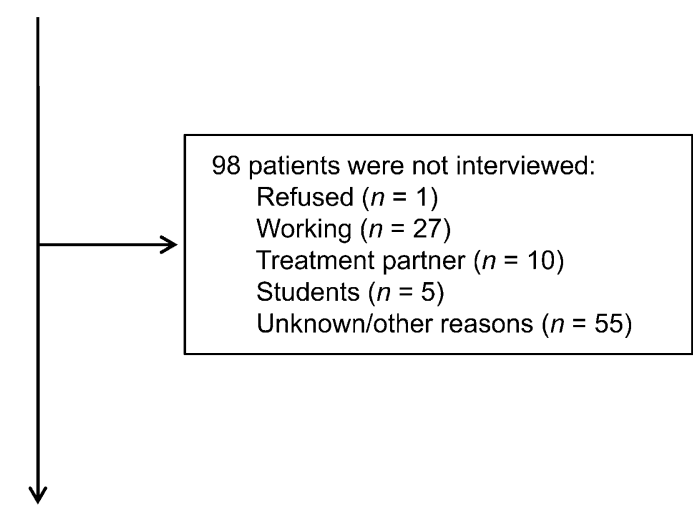

Interviewed PTB patients who met inclusion criteria $(n=561)$

Figure Flow chart of the study participants. $\mathrm{TB}=$ tuberculosis; $\mathrm{MDR}-\mathrm{TB}=$ multidrug-resistant $\mathrm{TB} ; \mathrm{PTB}=$ pulmonary TB. at the scheduled time for the following reasons: 1 patient refused, 27 were working, 10 had another person collect their medicine for them, 5 were students and 55 for unknown or other reasons (Figure).

The demographic characteristics of the study participants $(n=561)$ are shown in Table 1 . The mean

Table 1 Demographic characteristics of study participants

\begin{tabular}{|c|c|c|}
\hline Characteristic & Mean \pm SD & $n(\%)$ \\
\hline $\begin{array}{l}\text { Age, years } \\
18-30 \\
31-50 \\
51-80\end{array}$ & $41.87 \pm 15.6$ & $\begin{array}{l}166(29.6) \\
205(36.5) \\
190(33.9)\end{array}$ \\
\hline $\begin{array}{l}\text { Sex } \\
\text { Male } \\
\text { Female }\end{array}$ & & $\begin{array}{l}367(65.4) \\
194(34.6)\end{array}$ \\
\hline $\begin{array}{l}\mathrm{BMI}, \mathrm{kg} / \mathrm{m}^{2} \\
\quad<18.5 \\
18.5-25 \\
\geqslant 25\end{array}$ & $19.65 \pm 3.28$ & $\begin{array}{c}228(40.6) \\
294(52.4) \\
39(7.0)\end{array}$ \\
\hline $\begin{array}{l}\text { Type of treatment } \\
\text { New } \\
\text { Retreatment }\end{array}$ & & $\begin{array}{l}421(75.0) \\
140(25.0)\end{array}$ \\
\hline $\begin{array}{l}\text { Sputum smear status } \\
\text { Smear-positive } \\
\text { Smear-negative }\end{array}$ & & $\begin{array}{l}273(48.7) \\
288(51.3)\end{array}$ \\
\hline $\begin{array}{l}\text { Treatment phase } \\
\text { Intensive } \\
\text { Continuation }\end{array}$ & & $\begin{array}{l}230(41.0) \\
331(59.0)\end{array}$ \\
\hline $\begin{array}{l}\text { Employment status } \\
\text { Employed } \\
\text { Unemployed }\end{array}$ & & $\begin{array}{l}266(47.4) \\
295(52.6)\end{array}$ \\
\hline $\begin{array}{l}\text { Monthly income, pesos* } \\
<5000 \\
5000-10000 \\
>10000 \\
\text { Missing }\end{array}$ & & $\begin{array}{c}203(36.2) \\
220(39.2) \\
98(17.5) \\
40(7.1)\end{array}$ \\
\hline $\begin{array}{l}\text { Marital status } \\
\text { Married } \\
\text { Single } \\
\text { Cohabitating } \\
\text { Widowed/separated } \\
\text { Family member }\end{array}$ & 5.87 & $\begin{array}{r}204(36.4) \\
157(28.0) \\
106(18.9) \\
94(16.7)\end{array}$ \\
\hline $\begin{array}{l}\text { Education level } \\
\text { None } \\
\text { Elementary } \\
\text { High school } \\
\text { Vocational/college }\end{array}$ & & $\begin{array}{c}5(0.9) \\
180(32.1) \\
256(45.6) \\
120(21.4)\end{array}$ \\
\hline Total years of education & 8.35 & \\
\hline $\begin{array}{l}\text { Alcohol drinking } \\
\text { Never drinker } \\
\text { Former drinker } \\
\text { Current drinker }\end{array}$ & & $\begin{array}{c}151(26.9) \\
357(63.6) \\
53(9.5)\end{array}$ \\
\hline $\begin{array}{l}\text { Smoking } \\
\text { Never smoker } \\
\text { Former smoker } \\
\text { Current smoker }\end{array}$ & & $\begin{array}{c}236(42.1) \\
274(48.8) \\
51(9.1)\end{array}$ \\
\hline $\begin{array}{l}\text { SHS exposure } \\
\text { Not exposed } \\
\text { Exposed }\end{array}$ & & $\begin{array}{l}242(43.1) \\
319(56.9)\end{array}$ \\
\hline Symptoms $\geqslant 4$ & & $133(23.7)$ \\
\hline$A D R s \geqslant 4$ & & $188(33.5)$ \\
\hline MRC dyspnoea grade $\geqslant 3$ & & $98(17.5)$ \\
\hline FSSQ score $\leqslant 3.5$ & & $68(12.1)$ \\
\hline
\end{tabular}

* 1 US dollar $=43.87$ Philippine peso.

$\mathrm{SD}=$ standard deviation; $\mathrm{BMI}=$ body mass index; $\mathrm{SHS}=$ second-hand smoke; $A D R=$ adverse drug reaction; $M R C=$ Medical Research Council; FSSQ = Functional Social Support Questionnaire. 
age of the participants was 41.9 years; $65.4 \%$ were male. The body mass index (BMI) of $40.6 \%$ of the participants was $<18.5 \mathrm{~kg} / \mathrm{m}^{2}$. In total, $25.0 \%$ of the study participants were undergoing retreatment; $51.8 \%$ of the patients with newly diagnosed PTB and 39.3\% of the retreatment patients were smear-positive.

Depressive state among TB patients is shown in Table 2 . In total, $16.8 \%$ of the study participants were classified as depressive, with a cut-off score of 10 on the PHQ-9. Of the nine questions in the PHQ-9 questionnaire, general fatigue and difficulty in sleeping or excessive sleeping were prevalent symptoms: $51.3 \%$ complained of feeling tired or having little energy, $48.0 \%$ of the patients reported difficulty in sleep-
Table 2 Depressive state among PTB patients

\begin{tabular}{lcc}
\hline & PHQ-9 & \\
Depressive state & score & $n(\%)$ \\
\hline Non-depressive state & $0-4$ & $305(54.5)$ \\
& $5-9$ & $161(28.7)$ \\
Depressive state & $10-14$ & $67(12.0)$ \\
& $15-19$ & $18(3.2)$ \\
& $20-27$ & $9(1.6)$ \\
\hline
\end{tabular}

PTB $=$ pulmonary tuberculosis; $\mathrm{PHQ}=$ Patient Health Questionnaire.

ing or too much sleep; and $12.8 \%$ of patients felt that they would be better off dead or hurting themselves in some way.

Table 3 Univariate and multivariate analysis for depression among PTB patients

\begin{tabular}{|c|c|c|c|c|}
\hline & Crude OR $(95 \% \mathrm{Cl})$ & $P$ value & aOR $(95 \% \mathrm{Cl})$ & $P$ value \\
\hline $\begin{array}{l}\text { Age, years } \\
18-30 \\
31-50 \\
51-80\end{array}$ & $\begin{array}{l}1.00 \\
0.78(0.44-1.38) \\
1.24(0.72-2.13)\end{array}$ & $\begin{array}{l}0.39 \\
0.43\end{array}$ & $\begin{array}{l}0.88(0.43-1.80) \\
1.81(0.82-4.01)\end{array}$ & $\begin{array}{l}0.72 \\
0.15\end{array}$ \\
\hline $\begin{array}{l}\text { Sex } \\
\quad \text { Male } \\
\text { Female }\end{array}$ & $\begin{array}{l}1.00 \\
1.21(0.77-1.91)\end{array}$ & 0.42 & $1.19(0.68-2.09)$ & 0.53 \\
\hline $\begin{array}{l}\text { BMl, } \mathrm{kg} / \mathrm{m}^{2} \\
\quad \geqslant 18.5 \\
<18.5\end{array}$ & $\begin{array}{l}1.00 \\
2.96(1.87-4.69)\end{array}$ & $<0.001$ & $\begin{array}{l}1.00 \\
2.16(1.25-3.73)\end{array}$ & 0.005 \\
\hline $\begin{array}{l}\text { Type of treatment } \\
\text { New cases } \\
\text { Retreatment }\end{array}$ & $\begin{array}{l}1.00 \\
1.44(0.89-2.35)\end{array}$ & 0.14 & & \\
\hline $\begin{array}{l}\text { Sputum smear } \\
\text { Negative } \\
\text { Positive }\end{array}$ & $\begin{array}{l}1.00 \\
1.12(0.72-1.74)\end{array}$ & 0.24 & & \\
\hline $\begin{array}{l}\text { Treatment phase } \\
\text { Intensive } \\
\text { Continuation }\end{array}$ & $\begin{array}{l}1.00 \\
0.68(0.44-1.06)\end{array}$ & 0.09 & $0.84(0.49-1.44)$ & 0.53 \\
\hline $\begin{array}{l}\text { Employment status } \\
\text { Employed } \\
\text { Unemployed }\end{array}$ & $\begin{array}{l}1.00 \\
0.57(0.36-0.90)\end{array}$ & 0.017 & & \\
\hline $\begin{array}{l}\text { Monthly income, pesos* } \\
\quad<5000 \\
\geqslant 5000\end{array}$ & $\begin{array}{l}1.00 \\
0.57(0.36-0.92)\end{array}$ & 0.02 & & \\
\hline $\begin{array}{l}\text { Marital status } \\
\text { Married } \\
\text { Single } \\
\text { Cohabitating } \\
\text { Separated/widowed }\end{array}$ & $\begin{array}{l}1.00 \\
2.07(1.12-3.83) \\
2.68(1.40-5.12) \\
2.63(1.35-5.14)\end{array}$ & $\begin{array}{l}0.02 \\
0.003 \\
0.005\end{array}$ & $\begin{array}{l}1.00 \\
2.25(0.97-5.21) \\
3.34(1.52-7.37) \\
1.87(0.86-4.05)\end{array}$ & $\begin{array}{l}0.058 \\
0.003 \\
0.11\end{array}$ \\
\hline $\begin{array}{l}\text { Education level } \\
\text { None/elementary } \\
\text { High school } \\
\text { Vocational/college }\end{array}$ & $\begin{array}{l}1.00 \\
0.82(0.51-1.34) \\
0.48(0.24-0.95)\end{array}$ & $\begin{array}{l}0.44 \\
0.036\end{array}$ & & \\
\hline $\begin{array}{l}\text { Alcohol drinking } \\
\text { Never drinker } \\
\text { Former drinker } \\
\text { Current drinker }\end{array}$ & $\begin{array}{l}1.00 \\
1.07(0.65-1.77) \\
0.29(0.08-1.00)\end{array}$ & $\begin{array}{l}0.78 \\
0.049\end{array}$ & & \\
\hline $\begin{array}{l}\text { Symptoms } \geqslant 4 \\
A D R s \geqslant 4\end{array}$ & $\begin{array}{l}4.00(2.50-6.38) \\
3.98(2.51-6.31)\end{array}$ & $\begin{array}{l}<0.001 \\
<0.001\end{array}$ & $\begin{array}{l}2.31(1.30-4.12) \\
2.96(1.71-5.13)\end{array}$ & $\begin{array}{r}0.004 \\
<0.001\end{array}$ \\
\hline $\begin{array}{l}\text { MRC dyspnoea scale } \\
\text { Grade } 1 \\
\text { Grade } 2 \\
\text { Grade 3-5 } \\
\text { FSSQ (affective) }<3.67 \\
\text { FSSQ (confidant) }<3.4\end{array}$ & $\begin{array}{l}1.00 \\
2.65(1.49-4.72) \\
4.46(2.32-8.57) \\
1.39(0.75-2.58) \\
1.58(0.87-2.87)\end{array}$ & $\begin{array}{r}0.001 \\
<0.001 \\
0.30 \\
0.13\end{array}$ & $\begin{array}{l}1.00 \\
1.58(0.79-3.15) \\
2.84(1.32-6.12)\end{array}$ & $\begin{array}{l}0.20 \\
0.008\end{array}$ \\
\hline
\end{tabular}




\section{Univariate analysis}

In univariate analysis, BMI $<18.5 \mathrm{~kg} / \mathrm{m}^{2}$, unemployment, monthly income $>5000$ pesos ( US\$125), marital status (single, cohabitating, separated or widowed), low education level, four or more symptoms, four or more ADRs, and grade 2 or higher on the MRC dyspnoea scale were associated with depressive state (Table 3).

\section{Multivariate analysis}

Logistic regression analysis was performed to estimate risk factors for depressive state during treatment of PTB patients. Forty-two questionnaires $(7.5 \%)$ had 1 or more missing answers and were excluded from the multivariate analysis. The model showed that factors significantly associated with depressive state were $\mathrm{BMI}<18.5 \mathrm{~kg} / \mathrm{m}^{2}$ (aOR 2.16, 95\% CI 1.25-3.73, $P=0.005)$, marital status cohabitating compared with married (aOR 3.34, 95\%CI 1.52-7.37, $P=0.003$ ), 4 or more symptoms (aOR 2.31, 95\% CI 1.30-4.12, $P=0.004), 4$ or more ADRs (aOR 2.96, 95\%CI $1.71-5.13, P<0.001)$, grade 3 or higher on the MRC dyspnoea scale (aOR 2.84, 95\% CI 1.32-6.12, $P=$ $0.008)$ and low perceived confidant social support (aOR 2.16, 95\% CI 1.08-4.31, $P=0.03$; Table 3).

\section{DISCUSSION}

On assessing depressive state among PTB patients using the PHQ-9 questionnaire, $16.8 \%$ of the study participants were classified as having depression. The comorbidity of common mental disorders ranges from $19 \%$ in Turkey $^{7}$ to $80 \%$ of hospitalised patients in Pakistan. ${ }^{11}$ Compared with previous reports in other countries, the prevalence of depressive state among PTB patients was relatively low in the present study. A possible explanation for this result may be that only major depression was detected in the present study, whereas some previous studies included other common mental disorders such as generalised anxiety disorder.

Factors associated with depressive state were identified to be malnourishment, marital status of cohabitating, more than four symptoms and ADRs, and low perceived confidant social support. In contrast to previous studies, income level was not statistically associated with depressive state in multivariate analysis, although patients with lower income had significantly higher PHQ-9 scores in univariate analysis. This may be because the study participants were biased toward the economically poor group and patients with lower BMI tended to be poor. Marital status of not married, separated, divorced or widowed, and number of symptoms have been reported as risk factors for depression in earlier studies. ${ }^{12,14}$ As those who are not married, separated, divorced or widowed tend to be lonely and have less social support, ${ }^{23}$ marital status may have some relationship with depression. On the other hand, cohabitating without marriage may be related to depression, as it seems to reflect poor living conditions or unstable relationship with partners in local context. BMI was associated with depressive state in multivariate analysis. A causal relationship is not definite, as this study was cross-sectional; however, an improvement in nutritional status may lead to alleviation of depressive state.

Low perceived social support, especially in confidant relationship with family members or friends, was associated with depressive state. Instrumental or affective support is obviously important, but the study results suggest that the existence of persons who can share emotional and social problems with the patient plays an important role in improving one's mental status. It would thus be desirable to recruit social workers whom patients can consult about psychosocial problems, including economic matters, in the health centres.

Depression is associated with poor adherence to medication in the treatment of chronic diseases, ${ }^{13}$ and may be related to medication adherence in TB patients, although we could not assess the relationship in this study. Screening and follow-up for depression are recommended for TB patients, which could reduce the TB burden by increasing treatment adherence. In addition to medical treatment, mental health support among TB patients may lead to improved treatment outcomes, although providing mental health support may be challenging in resource-limited settings.

The present study has several limitations. First, as the PHQ-9 questionnaire has not been sufficiently evaluated in the general population in the Philippines, the PHQ-9 results should be interpreted with caution. As cultural differences may negatively affect the validity of the questionnaire, normative data for the Filipino population will need to be assessed. Second, PHQ-9 is a screening rather than a diagnostic tool for major depressive disorders, and patients may be misclassified, especially as false-positives, as higher PHQ-9 scores could be attributed to somatic symptoms caused by TB. However, taking into consideration the low prevalence of depressive state in this study compared with previous studies, ${ }^{6-12,14}$ it seems reasonable to conclude that the false-positive rate was not high. The cut-off score in TB patients requires further study and assessment. Third, it was difficult to determine a causal relationship between TB and depression, as this was a cross-sectional study. Fourth, as the study was conducted in an economically deprived urban area in Manila, it would be difficult to extrapolate the results to other settings. However, the study results might be applied to other, similar places in the Philippines. Fifth, comparisons between subjects who were interviewed and those who were not showed that participants were older than non-participants (41.9 vs. 36.7 years, $P=0.002$ ); however, no difference was seen in sex distribution. 
This difference may have led to selection bias. Finally, the present study was conducted using face-to-face interviews, which may result in misclassification of smoking status, alcohol consumption and exposure to second-hand smoke due to social desirability bias.

To overcome these limitations, the PHQ-9 questionnaire needs to be validated in the general Filipino population. A well-designed study, such as a cohort study, is needed to confirm the causal relationship between each factor and depression.

\section{CONCLUSION}

This study describes depressive state among PTB patients and identifies associated factors in an economically depressed area in the Philippines. As depressive state among PTB patients is common, screening for depression in DOTS clinics can identify people who need psychosocial assessment, support and treatment, especially for those who are malnourished and have poor confidant social support.

\section{Acknowledgements}

The authors appreciate the support of the technical and administrative staff of Research Institute of Tuberculosis/Japan AntiTuberculosis Association Philippines, and cooperation from staff in each health centre and non-government organizations. In addition, they thank P Agujo, Chief of Division of TB Control; R Cando, District Health Officer; G Inocencio, District Supervisor/NTP Nurse Coordinator; and A Vianzon, NTP Medical Coordinator, for arranging and helping in the implementation of data collection. They also thank all patients who participated in the study, and research assistants who conducted interviews.

This study was conducted in partial fulfilment of research for a Master's thesis of the first author, and was funded by the Graduate School of International Health Development, Nagasaki University.

Conflict of interest: none declared.

\section{References}

1 World Health Organization. Global tuberculosis report, 2012. WHO/HTM/TB/2012.6. Geneva, Switzerland: WHO, 2012. http://apps.who.int/iris/bitstream/10665/75938/1/97892415 64502_eng.pdf Accessed November 2013.

2 National Statistics Office. Philippines National Demographic and Health Survey 2008. Pasay City, The Philippines: NSO, 2009.

3 Tupasi T E, Radhakrishna S, Chua J A, et al. Significant decline in the tuberculosis burden in the Philippines ten years after initiating DOTS. Int J Tuberc Lung Dis 2009; 13: 1224-1230.

4 Moussavi S, Chatterji S, Verdes E, Tandon A, Patel V, Ustun B. Depression, chronic diseases, and decrements in health: results from the World Health Surveys. Lancet 2007; 370: 851-858.

5 Kamran S, Najma S. Treatment of common mental disorders in primary care in low- and middle-income countries. Trans $\mathrm{R}$ Soc Trop Med Hyg 2007; 101: 957-958.

6 Aghanwa H S, Erhabor G E. Demographic/socioeconomic factors in mental disorders associated with tuberculosis in southwest Nigeria. J Psychosom Res 1998; 45: 353-360.
7 Aydin I O, Ulusahin A. Depression, anxiety comorbidity, and disability in tuberculosis and chronic obstructive pulmonary disease patients: applicability of GHQ-12. Gen Hosp Psychiatry 2001; 23: 77-83.

8 Husain M O, Dearman S P, Chaudhry I B, Rizvi N, Waheed W. The relationship between anxiety, depression and illness perception in tuberculosis patients in Pakistan. Clin Pract Epidemiol Ment Health 2008; 4: 4. http://www.cpementalhealth.com/ content/4/1/4 Accessed November 2013.

9 Aamir S, Aisha. Co-morbid anxiety and depression among pulmonary tuberculosis patients. J Coll Physicians Surg Pak 2010; 20: 703-704.

10 Kruijshaar M E, Lipman M, Essink-Bot M-L, et al. Health status of UK patients with active tuberculosis. Int J Tuberc Lung Dis 2010; 14: 296-302.

11 Sulehri M A, Dogar I A, Sohail H, et al. Prevalence of depression among tuberculosis patients. APMC 2010; 4: 133-137.

12 Peltzer K, Naidoo P, Matseke G, Louw J, McHunu G, Tutshana B. Prevalence of psychological distress and associated factors in tuberculosis patients in public primary care clinics in South Africa. BMC Psychiatry 2012; 12: 89. http://www.biomed central.com/1471-244X/12/89 Accessed November 2013.

13 Grenard J L, Munjas B A, Adams J L, et al. Depression and medication adherence in the treatment of chronic diseases in the United States: a meta-analysis. J Gen Intern Med 2011; 26: $1175-1182$.

14 Issa B A, Yussuf A D, Kuranga S I. Depression comorbidity among patients with tuberculosis in a university teaching hospital outpatient clinic in Nigeria. Ment Health Fam Med 2009; 6: 133-138.

15 Department of Health. Manual of procedures for the National Tuberculosis Control Program, Philippines. 4th ed. Manila, The Philippines: DOH, 2005.

16 Spitzer R L, Kroenke K, Williams J B W. Validation and utility of a self-report version of PRIME-MD: the PHQ Primary Care Study. JAMA 1999; 282: 1737-1744.

17 Kroenke K, Spitzer R L, Williams J B W. The PHQ-9: validity of a brief depression severity measure. J Gen Intern Med 2001; 16: 606-613.

18 Manea L, Gilbody S, McMillan D. Optimal cut-off score for diagnosing depression with the Patient Health Questionnaire (PHQ-9): a meta-analysis. Can Med Assoc J 2012; 184: E191E196.

19 Stafford L, Berk M, Jackson H J. Validity of the Hospital Anxiety and Depression Scale and Patient Health Questionnaire-9 to screen for depression in patients with coronary artery disease. Gen Hosp Psychiatry 2007; 29: 417-424.

20 Khamseh M E, Baradaran H R, Javanbakht A, Mirghorbani M, Yadollahi Z, Malek M. Comparison of the CES-D and PHQ-9 depression scales in people with type 2 diabetes in Tehran, Iran. BMC Psychiatry 2011; 11: 61.

21 Broadhead W E, Gehlbach S H, de Gruy F V, Kaplan B H. The Duke-UNC Functional Social Support Questionnaire. Measurement of social support in family medicine patients. Med Care 1988; 26: 709-723.

22 Bestall J C, Paul E A, Garrod R, Garnham R, Jones P W, Wedzicha J A. Usefulness of the Medical Research Council (MRC) dyspnoea scale as a measure of disability in patients with chronic obstructive pulmonary disease. Thorax 1999; 54: 581-586.

23 Carter G C, Cantrell R A, Zarotsky V, et al. Comprehensive review of factors implicated in the heterogeneity of response in depression. Depress Anxiety 2012; 29: 340-354. 
CONTEXTE: La dépression, comme la tuberculose (TB), sont des problèmes de santé publique universels qui ont un impact significatif sur la santé. Cependant, la survenue de dépression chez des patients tuberculeux n'a pas fait l'objet d'investigations approfondies aux Philippines. овJECTIF : Evaluer la prévalence de la dépression chez les patients atteints de TB pulmonaire (TBP) et identifier les facteurs associés à la dépression à Manille.

SCHÉMA : Une étude transversale de patients tuberculeux a été réalisée dans 10 centres de santé publique et dans dispensaires gérés par des organisations nongouvernementales offrant le traitement DOTS dans le 1e district de Tondo, Manille. Au total, 561 patients PTB ont bénéficié d'entretiens individuels reposant sur un questionnaire structuré.
RÉ SULTATS : Un état dépressif a été identifié chez 16,8\% des patients. L'analyse en régression logistique a identifié les facteurs de risque suivants : un index de masse corporelle $<18,5 \mathrm{~kg} / \mathrm{m}^{2}$, une cohabitation hors mariage par rapport au mariage, la présence de 4 symptômes ou plus, la survenue de 4 effets secondaires du traitement, une dyspnée de stade 3 ou plus selon le score du MRC et un soutien social perçu comme faible et peu fiable.

CONCLUSION : Un état dépressif est fréquent chez les patients atteints de TBP dans des régions pauvres, et son dépistage dans le cadre des soins de santé primaires permet d'identifier les patients qui ont besoin d'un soutien et d'un traitement, surtout lorsqu'ils sont malnutris et ont peu de soutien social.
MARCO DE REFERENCIA: La depresión y la tuberculosis (TB) son problemas mundiales de salud pública con importantes repercusiones sanitarias. Sin embargo, no se ha investigado en profundidad el estado depresivo en los pacientes aquejados de TB en las Filipinas.

OBJETIVO: Evaluar el estado depresivo en los pacientes con tuberculosis pulmonar (TBP) y definir los factores que se asocian con este estado en Manila.

MÉTODOS: Se llevó a cabo un estudio transversal de pacientes con diagnóstico de TBP en 10 centros de salud pública y dos consultorios administrados por organizaciones no gubernamentales que suministran el tratamiento antituberculoso DOTS en el Distrito I en Tondo, Manila. Se practicaron entrevistas directas mediante un cuestionario estructurado a 561 pacientes con TBP.

RESULTADOS: Se encontró un estado depresivo en 16,8\% de los pacientes que participaron en el estudio. Un análi- sis de regresión logística puso en evidencia que un índice de masa corporal inferior a $18,5 \mathrm{~kg} / \mathrm{m}^{2}$, el estado civil de cohabitación en comparación con estar casado, la presencia de 4 o más síntomas y de 4 o más reacciones adversas a los medicamentos, una puntuación de $\geqslant 3$ en la escala de disnea del Consejo de Investigaciones Médicas del Reino Unido y la percepción de un bajo grado de confianza en el respaldo social fueron factores asociados de manera significativa con el estado depresivo.

CONCLUSIÓn: El estado depresivo es frecuente en los pacientes con TBP en una zona económicamente desfavorecida; la detección sistemática de la depresión en los entornos de atención primaria de salud puede reconocer a los pacientes que precisan apoyo y tratamiento, sobre todo los pacientes desnutridos y con débil respaldo social. 